\title{
An end and a beginning for the gift?
}

\section{Marilyn Strathern}

\section{OpenEdition}

\section{Journals}

Electronic version

URL: http://journals.openedition.org/jso/6094

DOI: 10.4000/jso.6094

ISSN: $1760-7256$

\section{Publisher}

Société des océanistes

\section{Printed version}

Date of publication: 15 December 2010

Number of pages: 119-128

ISBN: 978-2-85430-027-7

ISSN: 0300-953x

\section{Electronic reference}

Marilyn Strathern, «An end and a beginning for the gift? », Journal de la Société des Océanistes [Online], 130-131 | 2010, Online since 15 December 2013, connection on 13 June 2020. URL : http:// journals.openedition.org/jso/6094; DOl : https://doi.org/10.4000/jso.6094

(C) Tous droits réservés 


\section{An end and a beginning for the gift?}

by

\section{Marilyn STRATHERN*}

\begin{abstract}
Bernard Juillerat's argument about the way, in interpretations of Melanesian material, the gift has often been tied to reciprocity embeds the gift in a psychoanalytically informed universe. The power of his argument is acknowledged. Stepping outside such a universe, this article accords a different kind of power to his observations. It shows how they prompt some anthropologically interesting questions about practices of organ and tissue donation in North America. For where Juillerat would detach the gift from reciprocity, some of those engaged in debates over the ethics of donation would like to see reciprocity attached to the gift. What Euro-American paradigm underlies these arguments?
\end{abstract}

Keywords: Gift exchange, Yafar of Papua New Guinea, blood donation, gamete donation, mothers, altruism

In a co-edited volume put together to promote mutual understanding between Francophone and Anglophone anthropologists (Jeudy-Ballini and Juillerat, 2002), Bernard Juillerat threw down a challenge to what had become orthodoxy in much (not all) of the English-language literature on Melanesia. It is of course a nice point that the orthodoxy had a lineage of French origin, in the work of Marcel Mauss. I refer to Juillerat's revisiting of the concept of the gift, or rather of the place the gift has held in the anthropological paradigm of social exchange. Anticipated in the Introduction to the volume, and followed through by other contributors, his own

\section{RÉSUMÉ}

Dans son argument sur la façon dont les interprétations des matériaux ethnographiques mélanésiens lient souvent le don à la réciprocité, Bernard Juillerat intègre le don à un univers marqué par la psychanalyse. La force de son argument a été reconnue. Se situant en dehors d'un tel univers, l'article accorde aux observations de cet auteur une force d'un autre type. Il montre comment ces observations soulèvent d'intéressantes questions anthropologiques pour aborder les pratiques de don d'organes et de tissus en Amérique du nord. Car là où Juillerat dissocierait le don de la réciprocité, certains des spécialistes engagés dans les débats sur l'éthique de ces dons aimeraient y voir associée de la réciprocité. Par quel paradigme propre à l'Euro-Amérique ces arguments sont-ils sous-tendus?

Mots-ClÉs : échange de dons, Yafar de Papouasie Nouvelle-Guinée, don de sang, don de gamètes, mères, altruisme

chapter (written initially in 1996) has an unequivocal title:

"The other side of the gift: from desire to taboo. Representations of exchange and oedipal symbolism among the Yafar, Papua New Guinea.»

I take up the challenge in order neither to criticize nor concur with Juillerat's model. He offers us a coherent and persuasive account in his interpretation of Yafar, and I do not propose to disturb it. Yet from today's vantage point it strikes a chord of a kind that he might not have foreseen. In acknowledgement of his contribution to anthropology at large, my informal and

* Girton College, University of Cambridge, ms10026@cam.ac.uk 
speculative comments offer a brief footnote on paradigms.

\section{Two exhortations}

Juillerat is not the first Melanesianist, and surely will not be the last, to have taken issue with prevailing assumptions about the reciprocity being signalled in the gift. It is the way he does it, and the forcefulness of his demonstration, that is striking. First he is unequivocal about confronting Mauss, he and his co-editor declaring that their account is «opposed to what Mauss wrote about the obligations that structure the logic of exchange» (Jeudy-Ballini and Juillerat, 2002: 11). Second, he wishes to retain the concept of «gift» while disentangling it from «reciprocity» and, to the extent that it is entailed, «exchange». Indeed one could argue that the effect is to give the gift new life, keeping the scope of Mauss's general endeavour by showing how it may be newly thought across a range of situations. It is specifically Mauss's original emphasis on «obligation» in the formulation of reciprocity as the motor for exchange that is the problem.

«Melanesian ethnography shows that (the intention of) giving does not necessarily entail the obligation of receiving or reciprocating.» (2002: 11, original brackets)

In its place he puts desire and its psychic consequences. He nonetheless continues to use the vocabulary of gift exchange, in effect dividing gifts into those that are reciprocated and those that are not. To allow theoretical room for the latter, he concludes the chapter saying,

«we should pursue the unshackling of gift-giving from exchange, to which Lévi-Strauss' theory bound it.» (Juillerat, 2002: 183)

It is in effect an exhortation: Detach reciprocity from the gift!

There are all kinds of reasons for being interested in Juillerat's proposition. I am not just thinking of the very considerable and still lively debates in anthropology to which it contributes, and which regrettably have to be ignored here, but how it might sit with perspectives from elsewhere'. I am particularly struck by having recently come across a counter-exhortation: Tie reciprocity to the gift!

This is a plea that comes from the other side of the world, nothing to do with the kinds of materials on which Juillerat bases his account. But it does come from the same Euro-American world (if I can subsume both French-speaking and English-speaking orientations that way) that gives us the concept of the gift in the first place. There is a more ideationally specific lineage here, for a powerful voice in two areas of that world has been Titmuss's The Gift Relationship (1997); in that book the author prefaced a typology of blood donors with a consideration of Mauss and Lévi-Strauss. Comparing the UK and the US, Titmuss offered a sociological disquisition on policy for blood donation programmes. Indeed, since it first appeared in 1970, his book has been a major influence on the extent to which the gift has been embraced as model for such donations; above all the work is evoked for tying the gift to what we could call a Euro-American substitution of, if not negation of, reciprocity, «altruism». Through the words of one commentary on Titmuss's argument, the gift of blood in the modern welfare state is construed as:

«voluntary, not compulsory, and the recipient is under no personal pressure to reciprocate. It is given not because the giver expects a return, but as an act of voluntary altruism and social duty.» (Waldby and Mitchell, 2006: 15)

In the UK, the altruistic impetus has been explicitly upheld through policy measures that detach commercial transactions in blood and blood products from the primary act of voluntary donation ${ }^{2}$. Moreover, the altruistic gifting of blood has become the model for other donation schemes that have been developed since - for organ and tissue transplants of all kinds, and for gametes and embryos. In the US, where payments have long been acceptable for blood products and gametes, organ and tissue donations by contrast are required to be altruistic. «Altruism» emerges as the appropriate ethical stance for donors of body parts, and in this arena an overarching moral entity, «society $»^{3}$ can be a beneficiary. However, this may be an era that has exhausted itself.

1. In the context of diverse contrasts that have been posited between Melanesia and Amazonia, especially those that turn on the presence and absence of exchange relations, Juillerat's material on the hunting and gardening Yafar might be very germane. As Juillerat notes in his chapter, the Yafar life-cycle is conspicuously devoid of the kinds of overt exchange relations one finds across many parts of Melanesia, let alone ceremonial or agonistic exchange.

2. American openness to the morality of commerce is evident in the extent to which in the US for-profit commercial plasma companies supplement blood collecting by not-for-profit hospitals.

3. As the welfare state (Titmuss), the nation (see the contributions to Copeman, 2009), or the future of international research (Waldby and Mitchell, 2006). Strathern (1992) offers a commentary from the late 1980s. 
Two studies (Goodwin, 2006; Waldby and Mitchell, 2006) on tissue and organ circulation (transplantation, procurement), drawing mainly from materials on the US but also from the UK, explicitly question the future of Titmuss's gift relationship. If until now conventions about the donation of body parts as altruistic «gifts of life» have held the moral high ground in the advancement of transplantation practices and in the protocols of procurement agencies, they argue that the model of a gift free of proper compensation may have run its course. Too many counterexamples have built up, that is, examples of practices where «the gift form» simply «cannot function as a rejoinder or clear alternative to the incursion of market values into human tissue economies» (Waldby and Mitchell, 2006: 182). The way that most body tissue circulates in, to use a contrast first deployed in blood collection, «fractionated» rather than «whole» units; the uncertainty of donating for unknown research use; underground markets and the international traffic in organs, not to speak of the financial profit derived from procurement schemes, all in this view demand some re-thinking of the act of donation. It is in this context that Goodwin specifically advocates compensation for the families of deceased organ donors; the aim is to increase the overall supply ${ }^{4}$ and check the abuses of the black market. This is not in order to create a commodity market in body parts. On the contrary, and the point is anticipated by Radin (1996), it is argued that such payment need not detract from the idea of a gift in terms of benefit to others. When the gift is tied to exchange like this, and benefit is regarded as returning to the donor's family, the anthropologist might say that the gift is reciprocated. Whether the exchange is or is not market exchange is a separate issue.

Goodwin (2006) does not advocate direct compensation to living donors, and is concerned to keep the notion of altruism alive. I later turn to a proposition from Thompson (2007) about live donation, in which she recommends payment where it is not currently made, who goes on to sidestep the question of altruism by putting in its place the ethical principle of care (2010). The aim is a better procurement system, but also justice to the donor, and - although this phrase is not used - a form of direct reciprocity. I should briefly note that neither is an anthropologist (nor are Waldby and Mitchell whom I also cite), and while Goodwin refers to the gift in her criticism of Titmuss, and Thompson mentions gift theory, the terms reciprocity and gift exchange do not form their working vocabulary ${ }^{5}$. (One finds instead giving, donation, altruism, compensation.) The justification for my translating their arguments into anthropological idiom will I hope become evident. In the meanwhile, I remain with a general observation about the exhaustion of ideas.

It is not a model of donation as such that is exhausted. Rather, in these Euro-American narratives the gift (e.g. altruistic donations in the vernacular) is invariably opposed to the commodity, and what seems to have exhausted itself is the utility of that distinction. The argument put forward in respect of organ and tissue donation proposes that payment received for donation could be thought of as a «hybrid» combination of incentives. The point is not to jettison the idea of gift giving but to tie such giving to the kinds of transactions it was once thought to deny. Among other things, payment would signal a compulsion to reflect something of the transactional and medical complexity (of extraction) that defines the gift's career in this field. It seems to me that there is an interesting question here for present-day anthropology. Juillerat's position was that Mauss's stress on reciprocity is analytically exhausted in the sense that too many counter-examples have built up of areas of Melanesian life where gifts appear to be given without reciprocity. Do the two exhortations to which these approaches lead come from the same paradigm? If so, are we witnessing a paradigm made evident in its passing? If not so, then are the models used by Juillerat (and other EuroAmerican Melanesianists) and by the EuroAmerican commentators with respect to certain of their own practices (donations of body material) at all comparable?

The question about paradigms only makes sense as a question about whether, at the moment the notion of gift-giving is detached from or tied to exchange and reciprocity, we could argue that there is similar intellectual work going on. Let us look, then, at specific moments of detachment and attachment.

\section{Two mothers: Yafar}

The figure of the mother plays a central part in Juillerat's account, and two kinds appear in his

4. In dealing with the failure of the altruistic system in the US to ensure sufficient supply of much needed organs, she (Goodwin, 2006: 10) points to the avoidably high death rate for patients on waiting lists, especially among African Americans.

5. By contrast, the anthropologist Sharp (2006) has both «gift economy» and «reciprocity» in the index of her book on organ transplants in the US. 
chapter. The primordial Mother, who gives no less than the world, has as her shadow the (human) mothers of children with their nurturing gifts of milk - the «mother's selfless gift to her child», as the joint Introduction puts it (Jeudy-Ballini and Juillerat, 2001: 11). The mother-child relation of everyday interaction is ritually reactivated, we are told, when men beseech the maternal totem, the coconut palm in flower, to shed its abundance upon them. The flowers that fall are (likened to) milk, in turn an index of abundant game. The men of the two moieties reactivating the primordial Mother's fecundity render her as a counterpart to the paternal sago palm, which in the course of the same rite is cut and consumed. The inflorescence from the coconut, not normally eaten, is tasted and then given to hunting dogs who will demonstrate what the Mother provides. At the end of the hunting period, the bestowal complete, the flowering part is closed up.

The violence done to his account by my abstracting Juillerat's analysis from its psychoanalytic framing, and the psychic resonance that gift carries in this context, must be acknowledged. His whole point is the inadequacy of the kinds of explanations to which Mauss's social and (in the emphasis on the obligations to receive and reciprocate) juridical approach are addressed. I might add that is also a violence not to do justice to the incomparable order of detail that he provides, here and across his work. My interest is in the tenacity of the gift as a concept. What seems to conserve his own vocabulary of gifting in relation to the primordial Mother is the assumption that ordinary human mothers are «giving gifts» when they feed their children ${ }^{6}$. These mothers later eat of the pork that their brothers will have received as explicit payment for maternal milk; the meat comes from their sons' / sister's sons' hunting (Juillerat, 2002: 175-6). We could regard the brother-sister pair as the actor here, mother's brother as Yafar say being «the breast»; but Juillerat sees this as a redirection from the woman to her brother from whose hand she receives the pork, keeping the image of the mother as one who does not receive directly? The primordial Mother, on the other hand, while having a male counterpart in the paternal totem or «divine Father» seems, in this particular account, to have no such brother. However, her single breast, originally severed from the rest of her when parts of her body formed the world, was hung by the Father in the sky as the sun (Juillerat, 1992).

Juillerat (2002) focuses on the unreciprocated nature of the Yafar Mother's gift. It is a gift insofar as, following the vernacular pleading with an explicit reference to milk, the cry is for the Mother to "give» game to be hunted. Animals are itemized - pigs, cassowaries, possum and she is asked to give them all. The gift is unreciprocated, in Juillerat's view, insofar as it is totalizing: giving everything to people, she is not able to receive anything herself (2002: 165-6). There is, he asserts, no possibility of exchange. At the moment of detachment, when the coconut inflorescence is shaken over them, the men are mute recipients, indeed their eyes are averted, neither seeing nor being seen. The anxiety is that they will not receive anything, that they will not have achieved (in Juillerat's words) their desire for the mother's desire. The contrast is with their later being seen by the spirits, for whom they have left gifts, who make them gifts of game and their own active seeing of the animals they are going to shoot («scopic capture», 2002: 170171). Game is ultimately the Mother's gift, but return is made only to the more immediate spirits who enable hunters to see their prey. Given the sheer inappropriateness of the source of bounty desiring anything back, the Mother's own gift is detached from exchange. Yafar say that the whole world comes from the Mother's body.

What goes for the maternal gift of milk (game) from the totemic Mother goes too for the paternal sago from the totemic Father.

«From the standpoint of the gift, both substances are received and consumed [in the course of ritual] without compensation. Humans do not give the divine couple anything.» (2002: 164)

But the Father has other roles to play. Juillerat particularly deploys the figure of the Mother to make his general point about exchange; it is in the context of her bountiful and uncompensated bestowal that reciprocity seems beside the point. Even when reciprocity does appear so attached in (human) exchanges, Yafar prefer to get it over with as soon as possible: to put off reciprocating is, Juillerat says, regarded as a bad custom. Elsewhere in Papua New Guinea people may cultivate debts, and the anthropologist turns

6. One could as well analyse this from the perspective of unmediated relations, as can hold between mother and child; it would give us the idea of an exchange (in the impact of persons upon one another) without a gift. Apropos the emphasis on the mother, Juillerat describes how the reactivation of the primordial paternal semen is similarly «unreciprocated» (e.g. 2002: 164).

7. Jeudy-Ballini, who refers to the self-less nurture that comes from «the mother», nonetheless points to the «deferred, long-term reciprocity» to which human mothers look forward (Jeudi-Ballini and Juillerat 2002: 11, n.4). 
reciprocity into a structuring feature of social life, but here people hate to think of themselves as in debt. Juillerat seemingly detaches reciprocity from the gift at the moment when he nonetheless wishes to conserve Yafar men's desire for the Mother's abundance as at once an example of gift-giving and as an organizing feature of ritual action.

\section{Two mothers: North America}

In almost every respect it would seem alien to suggest a comparison with those caught up in the configurations of organ, blood - and other tissue - and gamete donations in North America. Here men and women contribute to schemes that circulate body parts between persons, and these days, when whole blood is normally broken down or fractionated into separable products and whole organ transfer is only a part of a much wider traffic in body tissue, it may be difficult to visualize a donor-recipient relationship.

However, such an imagined relationship has been understood as lying at the core of the impetus to donate. That does not mean that the parties should be identifiable, and the protection of donor anonymity has often meant keeping donor and eventual recipient(s) apart (strenuously defended in the case of organ transplant professionals, sometimes against people's own desires [Sharp, 2006]). Yet the person from whom the body part comes, whether alive or dead, continues to be called a «donor». The same term is used of course in Euro-American practices of giving to charity or otherwise in support of good causes, a depersonalized giving that nonetheless requires envisaging some kind of human recipient at the end of a chain of transactions. Imagining the absent recipient, or donor for that matter, plays a special part in gamete and specifically ova donation, as Konrad (2005) has described in the UK. In the US, recipients of organs may try to imagine their donors, and it has been reported that mothers of children who donated after an early death may seek out the person whose body now contains a living part of their child (Sharp, 2006: 196).

Now Goodwin (2006: 18) is not the first commentator, and certainly will not be the last, to observe that:

«human donations enter [the organ procurement and distribution system] altruistically and exit commercially.»

The engineering of tissues means that: «any donated tissue may be put to multiple uses and adopt multiple trajectories [including as items for trade]. [...] Tissue donation is thus transformed from an act of direct civic responsibility [...] into a complex network of donor-recipient relations heavily mediated by biotechnical processes and an institutional complex of tissue banks, pharmaceutical and research companies, and clinics.» (Waldby and Mitchell, 2006: 22)

all of which need to fund their services. If one adds to this the pressure of ever-present shortage, and the international black markets that spring up to meet demand from wealthy countries, there is a case for change to donation practices. Goodwin (2006: 21) proposes introducing remuneration to the relatives of deceased organ donors, in order to create a more open and equitable system; it would embrace «a transparent but limited market approach». Commodification with respect to organs is outlawed in the US. Yet there is a precedent of sorts, she notes, that shows "Americans' willingness to utilize markets to procure and allocate human resources» (2006: 21). She refers here to reproductive altruism (producing children to assist ailing siblings), and elsewhere to gamete (ova and sperm) donation as an example where "financial transactions in the body are [...] transparent» (2006: 160).

However, by contrast with sperm, eggs these days fall into one of two types. In the US there is no legal bar to making payments for ova, arguments often focusing on the appropriate scale of recompense (Thompson, 2007), insofar, that is, as the eggs are intended for reproductive purposes. The situation changes radically when it comes to those who donate eggs, and in some cases fertilized eggs (embryos), for research. There are thus two kinds of ova donors: the one whose eggs will help another to have a child, and the one whose eggs may be used for all kinds of research purposes, known and unknown. In the distribution of egg and embryonic tissue the recipient is not a person but a research project.

«The two kinds of donation should be kept separate even when some eggs are used for IVF [in vitro fertilization] and some for research as part of the very same act of donation.» (2007: 203)

Although women who become egg donors do not by that act become mothers themselves, in the context of fertility treatment they enable others to be mothers. This is obviously not so when eggs are destined for research; the gesture there is towards the ultimately therapeutic intention of those engaged in research to improve medicine at large. The donor is a first and foremost a «research subject», that is, one who 
contributes part of their bodily self to research, much as participants in clinical trials do.

Stem-cell research is currently a principal area in need of eggs, and embryos, which may in turn be fractionated and multiplied. As Thompson (2010) observes, once cell lines produced from reproductive material are in circulation, there is no way to control their diffusion. This includes diffusion through commercial ventures. In any event, she $(2007,2008)$ cannot see any reason why women who donate to research programs should not receive recompense. On the contrary, much as Goodwin argues, openness would help protect a system that could well find itself subject to some of the abuses of organ procurement. Thompson herself puts forward positive reasons why payment would assist not just the individual donor but the whole procurement and potential treatment system, and how it could be done in such a way as to avoid direct commercialization as such. She also deals, one by one, with reasons against payment. The goals behind each objection, she argues, could be met by innovations in practice (which she specifies in detail I do not give here), and none could not also be met under a paying regime. To give an anthropological summary: there are many advantages to reciprocity being tied to the gift.

Why does Thompson take such care in dealing with the reasons against payment? These turn out to be reasons why payment would distort the nature of the action, substantively why it would subvert the character of gift-giving. And what has to be conserved about gift-giving? This turns out to be a deeply rooted assumption that «altruism» is bound up with the gift, and is a principal motive in self / body giving.

Let me expand the point briefly. The ubiquitous vocabulary of donation makes of the body tissue a "gift of life». It entails, in its canonical Euro-American form, a notion of the autonomy of the voluntary act. This is partly what enables a gift to be a signifier of altruism. The giver legally bestows possession on another without obligation, and in that sense without self-interest, although all kinds of obligations and interests may accompany gift-giving practices. This kind of gift is «free» by contrast, above all, with commodities that circulate in market transactions, the type case of immediate reciprocity ${ }^{8}$. Donation is often presented as the antonym to commerce; indeed, the contrast is a plank in many donor programs (encouraging donors to give), and the rhetoric of the altruistic gift has as deep and widespread an appeal as commerce is regarded as inappropriate for transactions in human organs. We could almost say there is a taboo on speaking of the donation of body parts as though they could be objects of commerce. "Among the strongest ideological underpinnings of transplant medicine is the adamant denial of body commodification» (Sharp, 2006: 12), and outside the US that applies more widely than organ transplantation.

The ideology prescribes the type of person who, for certain purposes at least, is a suitable donor. In this view, body parts should come from sources in those who give voluntarily, not just out of fellow-feeling for others but in the sense that nothing has been extracted from them through undue inducement or coercion. Such attributes would be betrayed if donors sought recompense. Protocols of anonymity, where they are in place, uphold the image of the free and altruistic donor; conversely, at the other extreme, altruism is held in place by people acting intimately as kin do towards one another - the sister who donates eggs to a sister or the relative whose bone marrow can be matched with a patient's for kinship can also signal «self-less» intention. Such ideas belong to a broader nexus of concerns about the role of money in people's sense of themselves. On the one hand is the assumption that as soon as commerce enters the room altruism goes out of the window; on the other hand is the assumption that if reciprocation is monetary then it has an inevitable commodification-effect ${ }^{9}$.

Those who now argue for attaching «exchange» or «reciprocity» to the gift do not subscribe to these assumptions. The introduction of reciprocity may appeal to market arguments for exchange, but it may also visualize nonmarket ones. What is interesting about the proposal for recompense, in the accounts both from Goodwin (posthumous organ transplants) and Thompson (ova donation for research), is the way a notion of the gift endures. Introduce exchange, but attach it to the gift - don't get rid of gift as a concept! In asking why not, we might glimpse something of the interest of Juillerat's chapter.

Why not get rid of (the concept of) the gift? The figure of the altruistic donor, male or female in respect of organs, female in respect of eggs, carries with it an ethical aura. Goodwin (2006:

8. For a thorough exploration of the (anthropological and related) mythology here, see Konrad (2005).

9. Yet even if one concurs that donation is the antonym to commerce, one may note that reciprocity in the form of the obligation to return a gift is itself different from market exchange (commerce). Note that in English «payment» does not necessarily imply either a monetary or market transaction (one «pays» compensation for instance). 
21) is forthright about conserving altruism: her hybrid system for organ procurement is one «that supports altruistic procurement», for it «would allow for altruism and commoditization to mutually thrive». After all, in gamete donation, as we have seen, «[m]arket systems [...] coexist with altruism» (2006: 182). Thompson argues that it is the fear of driving out the ethical impulse of altruism that has prevented recompense in the past and clouded debate. Yet if we look at reproductive egg donation, she also posits (2007: 208), we find that the two kinds of motivation, «far from being incompatible, seem to bolster one another [...] [So] [i]t is wrong then to worry that being paid substitutes a financial for an altruistic motivation». The willing research subject can still be thought of as making a donation to science or to society. Ethical ends can still be met; donations can still be encouraged «for the right reasons» (2007: 209). In fact Thompson (2010) has recently put forward a suggestion for replacing the principle of altruism (as the donor's ideal motivation) with that of care (of the donor's body and person); what is conserved is the ethical stance.

But ethics for whom? Is it not above all «the system», that is, the processes of procurement and distribution, whose practices - for very good reason - must be kept ethical? Thompson's account of the traditional concept of ethics that required the egg donor, in the context of research, to receive no return is illuminating here.

In effect, it is the act of taking that the gift in this tradition renders ethical: the altruistic donor elicits ethical consideration from others.

«[P]rotection of potential egg donors has become the signature of ethical concern in the politics of stem cell research in California and elsewhere, and has emerged as the women's issue.» (Thompson, 2008: 117 , original italics)

In other words, protection ${ }^{10}$ of the (unrecompensed) research subject becomes the sign of ethical action on behalf of those engaged in the research, or indeed of those who subsequently make use of the material. The source is impeccable; tissue has been extracted appropriately. But for the appropriateness to be registered, the research subject must be seen to be exercising voluntary will. I quoted the observation that human donations, of organs and some tissues, enter the procurement system altruistically and exit commercially. Precisely: the initial extraction is appropriately of a gift. But obviously the gift has this character only at the identifiable point of extraction from the donor; further down the chain all kinds of other transactions may occur between actors in diverse roles. Perhaps we should not be surprised to find the figure of the donor sometimes gets rather special treatment.

If there is a specific point at which the Yafar material enlarges one's vision, it is here. One would not wish to stretch vernacular usage too far: American egg donors are not «mothers» in the way that Juillerat was able to envisage the promordial Yafar Mother. Yet there is something suggestive about the figure of the deity who pours forth her milk, «fractionated» into diverse species of game for the hunter. At least in some parts of United States, ethical tradition places at the heart of stem cell research an enchanted female. This anonymous figure is shrouded in a kind of sanctity, purified of intentions that may be sullied by thought of return ${ }^{11}$. She cannot, must not, receive anything back. Personifying the donation of all kinds of body parts, then, is the self-less donor to research who only has the long term need of others in mind. What is being ritualized here, or in secular terms enchanted, is an ethical stance towards procurement. In other words this figure sanctifies (ethicises) the transaction, just as the Yafar Mother bestows bountiful game on men who are then free to take whatever puts itself in their path.

The North American advocates of recompense would seemingly attach reciprocity to the gift at the moment when transactions in human tissue are also required to show their ethical sourcing; in conserving the idea of gift-giving as an organizing feature in procurement practices, they show that ethical action need not be compromised.

\section{End}

I do not know if there were any people from Yafar in Madang hospital, Papua New Guinea, at the time when Street (2009) was making her study of visualisation practices, but if there were they no doubt would have been aware of the extent to which the hospital required blood to do its work. To obtain blood the hospital runs a scheme by which patients request their relatives for donations, even if (because of blood type) it

10. The medical risks of egg extraction are widely known, and there are several areas of concern that Thompson describes

11. In relation to embryos, Thompson (2009) notes the severity of the ISSCR (International Society for Stem Cell Research) sample consent form that specifies that a donor can have no further interest in what has been given, and must understand there is no way in which any direct financial benefit can come from future commercial developments. 
is not their relatives' blood that they themselves receive. The procedures draw, she says:

«on prevalent notions of gift exchange in Papua New Guinea that consider the recipient as an active agent in the extraction of gifts from others.) (2007: 195)

From Juillerat's account, one might imagine that among the confusions that the hospital setting presented a Yafar patient, this would be another ${ }^{12}$ ! But they would perhaps recognize what Street also indicates, that blood transfusion does not seem to entail an ongoing process of reciprocation:

«it might be thought of as a point of finishing or completion after which the patient will be able to leave the hospital, and which contains all previous exchanges and transactions within itself.» (2007: 209)

Like Juillerat, the North American commentators cited here, advocates of reform or not, hold on to the concept of gifting. It was hoped that this excursus might reach a point where it became evident whether or not these diverse appeals to gift-giving and donation were doing similar intellectual work, that is, belonged to a common (Euro-American) paradigm of interpretation and analysis. A partial answer might be that common ground lies in the manner in which the assumptions that surround gifting lend themselves to larger descriptions of social life than interactions between donors and recipients might imply. The gift is held to have organizational effects.

And perhaps what teases anthropologists so about certain acts of gift-giving is the way they also epitomise how people's intentions resist organization. Insofar as the act can indeed be an intention of a kind (as Jeudy-Ballini and Juillerat indicated by their brackets [see above p. 120]), it is selective and discriminatory: the recipient is rendered passive. This would resonate with the emphasis that Juillerat gives to choice and the implied possibility of refusing to give or reciprocate (2007: 159) ${ }^{13}$. Caprice on the part of the donor (whether or not to give) contrasts with the uncertain but at least possible ability to measure people's actions through their relations with others, which is what reciprocated gift exchange or market exchange both afford. As it is, like male initiates in other Melanesian situations concerned as to whether they have demonstrably grown, the Yafar men who stand under the coconut are in a state of anxiety to whether or not flowers will fall into their upturned hands. Many, Juillerat tells us, will fail to receive, will not experience the Mother's gift ${ }^{14}$. Organ and tissue procurement programmes, research bodies and fertility clinics, always chronically short of raw material, have their hands outstretched too. What they so avidly desire cannot, they believe, be taken by coercion.

\section{Acknowledgements and Note}

Part of this material was aired in a Lecture for the Finnish Anthropological Society (December 2009), «Comparing concerns: some issues in organ and other donations». I am very grateful for comments received on this occasion, to Almut Schneider for her observations on an early draft, and to the editors of this special edition for their invitation to offer a contribution in honour of Bernard Juillerat.

I should add that the UK Nuffield Council on Bioethics has asked me to chair a Working Party to report on medical donations that involve the body. It is departing from its usual single-focus Reports to investigate issues surrounding procurement, donation and reward in what are presented as three areas: gamete donation, organ / blood donation and voluntary participation in clinical trials. The present paper was written before I assumed that position and before the Working Party was convened, and is based on entirely independent work. All opinions are mine as a social anthropologist, and nothing I say represents the views of the Council or of the Working Party, or of myself in the capacity of chair.

\section{BIBLIOGRAPHY}

Copeman Jacob (ed.) 2009. Blood Donation, Bioeconomy, Culture, spec. iss. Body and Society 15 (2), pp. 1-222.

JeUdy-BALlini Monique and Bernard JuILlERAT, 2002. Introduction. The social life of objects, in M. Jeudy-Ballini and B. Juillerat (eds), People and

12. She makes her own argument, following Waldby and Mitchell (2006), about the inadequacy of the gift / commodity distinction.

13. It is the «risk of not receiving [...] which creates the negative, hidden face of the Yafar ideology of the gift» (Juillerat, 2002: 173). Of course the risk is not confined to unreciprocated exchanges, and the performed passivity of recipients in all kinds of exchange situations is widely reported in Papua New Guinea. But, and also of course, Juillerat's account renders my question about paradigms superfluous: for him the psychoanalytic gift is the now present, now absent breast.

14. Directly, that is. All present taste the flowers. 
things: Social mediations in Oceania, Durham, N.C., Carolina Academic Press, pp. 3-25.

JuILlerat Bernard, 1992. 'The Mother's Brother is the Breast'. Incest and its prohibition in the Yafar Yangis, in B. Juillerat (ed.), Shooting the sun: Ritual and meaning in West Sepik, Washington, Smithsonian Institution Press, pp. 20-124.

_, 2002. The Other Side of the Gift: from Desire to Taboo. Representations of exchange and oedipal symbolism among the Yafar, Papua New Guinea, in M. Jeudy-Ballini and B. Juillerat (eds), People and things: Social mediations in Oceania, Durham, N.C., Carolina Academic Press, pp. 157-183.

Konrad Monica, 2005. Nameless Relations, Anonymity, Melanesia and reproductive gift exchange between British ova donors and recipients, Oxford, Berghahn.

GoodwIN Michele, 2006. Black Markets, the supply and demand of body parts, New York, Cambridge University Press.

RADIN Margaret, 1996. Contested Commodities, the trouble with trade in sex, children, body parts, and other things, Cambridge M.A., Harvard University Press.

Sharp Lesley, 2006. Strange Harvest, organ transplants, denatured bodies and the transformed self, Berkeley and Los Angeles, University of California Press.

Strathern Marilyn, 1992. Partners and Consumers, in M. Strathern, Reproducing the Future, essays on anthropology, kinship and the new reproductive technologies, Manchester, Manchester University Press.

STREeT Alice, 2009. Failed recipients: Extracting blood in a Papua New Guinea hospital, Body and Society 15 (2), pp. 193-215.

Thompson Charis, 2007. Why we should, in fact, pay for egg donation, Regenerative Medicine 2 (2), pp. 203-09.

-, 2008. Stem cells, women, and the new gender and science, in L. Schiebinger (ed.), Gendered Innovations in Science and Engineering, Stanford, Stanford University Press, pp. 109-130.

- 2010. Informed consent for the age of pluripotency and embryo triage: From alienation, anonymity, and altruism to connection, contact, and care, in $\mathrm{J}$. Nisker, F. Baylis, I. Karpin, C. McLoed and R. Mykitiuk (eds), The «Healthy» Embryo, social, biomedical, legal and philosophical perspectives, Cambridge, Cambridge University Press. [pagination not available]

Titmuss Richard, 1997 [1970]. The Gift Relationship, from human blood to social policy, edited by A. Oakley and J. Ashton, London, LSE Books.

WaldBy Catherine and Robert Mitchell, 2006. Tissue Economies, blood, organs, and cell lines in late capitalism, Durham, Duke University Press. 
